Original Article

\title{
Effects of combined open kinetic chain and closed kinetic chain training using pulley exercise machines on muscle strength and angiogenesis factors
}

\author{
Ki Soeng Jang ${ }^{1)}$, Sunghwun Kang ${ }^{2)}$, Sang Heon Woo ${ }^{1)}$, Ju Yong BaE ${ }^{1)}$, Ki OK Shin ${ }^{1)^{*}}$ \\ 1) Laboratory of Exercise Biochemistry, Department of Physical Education, College of Sports Science, \\ Dong-A University: Busan, Republic of Korea \\ 2) Laboratory of Exercise Physiology, Division of Sport Science, Kangwon National University, \\ Republic of Korea
}

\begin{abstract}
Purpose] This study investigated the effects of combined open kinetic chain and closed kinetic chain training using pulley exercise machines on muscle strength, anaerobic power, and blood levels of angiogenesis factors. [Subjects and Methods] Twenty male university students were equally divided between control and pulley training groups. The pulley-training group underwent 8 weeks of combined training. Open kinetic chain training consisted of 2 sets of 10 repetitions at $60 \%$ of one repetition maximum; closed kinetic chain training consisted of 2 sets of 10 repetitions of resistance exercise using the subject's own body weight. Isokinetic strength (trunk and knee), anaerobic power, vascular endothelial growth factor, angiopoietin-1, angiopoietin-2, and follistatin were analyzed. [Results] After 8 weeks, flexor and extensor muscle strength significantly increased in the trunk and knee; average and peak power also increased significantly. Angiopoietin 1 increased $25 \%$ in the control group and $48 \%$ in the pulley training group; vascular endothelial growth factor and follistatin increased significantly in the pulleytraining group after 8 weeks. [Conclusion] Eight weeks of combined training using pulley exercise machines effectively increased biochemical factors related to muscle growth, as well as muscle strength in the trunk and knees. Key words: Open kinetic chain, Closed kinetic chain, Angiogenesis factors
\end{abstract}

(This article was submitted Nov. 10, 2015, and was accepted Dec. 12, 2015)

\section{INTRODUCTION}

Resistance exercise using weight machines or body weight builds muscle strength, helps rehabilitate athletes, prevents injuries, and improves health in typical adults ${ }^{1)}$. Resistance exercises can be categorized biomechanically into open kinetic chain $(\mathrm{OKC})$ and closed kinetic chain $(\mathrm{CKC})$ exercises. $\mathrm{OKC}$ exercises result in isolated movement at a given joint and are effective when isolated strengthening for selected muscle groups is desired. In contrast, CKC exercises cause co-contraction of agonist and antagonist muscle groups ${ }^{2,3}$. $\mathrm{OKC}$ and $\mathrm{CKC}$ exercises are applied directly to everyday physical activities and exercise, and combined $\mathrm{OKC}$ and $\mathrm{CKC}$ training is recommended for treatment and rehabilitation ${ }^{1)}$. Thus, combined training is required not only for muscle strength improvement but also for muscle stabilization.

Meanwhile, resistance training increases oxygen supply and blood flow to skeletal muscles when they are scarce; this stimulates the growth of capillaries within the muscles and is called angiogenesis ${ }^{4,5}$. Angiogenesis factors include vascular endothelial growth factor (VEGF), angiopoietin 1 (Ang 1), and angiopoietin 2 (Ang 2). The major functions of VEGF are to increase the growth and movement of vascular endothelial cells ${ }^{6)}$ and to regulate capillaries within skeletal muscles ${ }^{7)}$. Ang

*Corresponding author. Ki Ok Shin (E-mail: kshin21@dau.ac.kr)

(C2016 The Society of Physical Therapy Science. Published by IPEC Inc.

This is an open-access article distributed under the terms of the Creative Commons Attribution Non-Commercial No Derivatives (by-nc-nd) License $<$ http://creativecommons.org/licenses/by-nc-nd/4.0/>. 
1 and Ang 2 both bind to Tie2 receptor ${ }^{8)}$. Ang 1 participates in stabilization of blood vessels ${ }^{9)}$, whereas Ang 2 participates in destabilization and remodeling ${ }^{10)}$. In addition, the skeletal muscle growth protein follistatin has a positive effect on muscle growth by suppressing myostatin activity ${ }^{11)}$. Acute and regular aerobic exercise is reported to upregulate angiogenesis factors $^{10,12,13)}$. However, there are still only a few reports clarifying the effects of regular resistance exercise on angiogenesis factors.

Thus, it is essential to investigate the effects of combined OKC and CKC training, which can selectively strengthen muscle groups and improve muscle coordination, to determine whether such training is effective for rehabilitation and improves the quality of physical activity. Hence, the aim of the present study was to investigate the effects of combined OKC and CKC training on muscle strength, anaerobic power, and blood levels of angiogenesis factors.

\section{SUBJECTS AND METHODS}

Twenty male college students with no medical problems were randomly divided into pulley training $(\mathrm{PT}, \mathrm{n}=10)$ and control $(\mathrm{CO}, \mathrm{n}=10)$ groups. To obtain valid results, the subjects were advised against participating in excessive physical and nonroutine social activities on the day before the experiments. Food intake was prohibited after 21:00 h on the day before the experiments, and fasting for more than $12 \mathrm{~h}$ was required for all subjects. Body composition, including height, weight, body mass index (BMI), percentage of body fat, and lean body mass (LBM), was assessed at the Dong-A University Laboratory using an established bioelectrical impedance method with a Venus 5.5 body composition analyzer (Jawon Medical, Gyeongsangbuk-do, Korea). Three days before the experiment, one repetition maximum (1RM) was performed to test the experiment by indirect methods ${ }^{14)}$. All volunteers underwent medical screening, including a health status interview and physical examination. Written informed consent was obtained from all subjects. The study was approved by Dong-A University Hospital's Institutional Review Board, and conducted in agreement with the Declaration of Helsinki.

The exercise program is shown in Table 1 . The training in this study was performed using pulley exercise machines (Welltech, Busan, Korea) that can be used for OKC and CKC training. OKC exercise was performed for 8 weeks at $60 \%$ of $1 \mathrm{RM}$, and the value of $1 \mathrm{RM}$ was recalibrated every 2 weeks. CKC exercise was performed using body weight loading. The order of exercise was 2 sets of 10 repetitions of OKC exercise, followed by 2 sets of 10 repetitions of CKC exercise. All subjects performed a warm-up and cool-down 3 times to calibrate the measuring equipment. Isokinetic strength testing for extension and flexion of the trunk $\left(60^{\circ} / \mathrm{s}\right)$ and knee $\left(60^{\circ} / \mathrm{s}\right)$ was performed with HUMAC NORM dynamometer (CSMI, Stoughton, MA, USA). Anaerobic capacity was measured using a Wingate test on a plate-loaded and friction-braked bicycle ergometer (Monark, Vansbro, Sweden). The items measured were average power (AP), peak power (PP), peak pedaling speed (PPS), and peak attainment time (PAT). Blood $(10 \mathrm{ml})$ was collected from subjects via the antecubital vein for analysis of serum samples after a 12-h overnight fast. Each blood sample was centrifuged for 15 minutes at 3,500 rpm at $4{ }^{\circ} \mathrm{C}$. The supernatant was decanted and stored in a deep freezer at $-80{ }^{\circ} \mathrm{C}$ until analysis. Serum total cholesterol (TC), high-density lipoprotein cholesterol (HDL-C), free fatty acid (FFA), and triglyceride (TG) concentrations were assayed using an enzyme-linked immunosorbent assay (ELISA) kit. Low-density lipoprotein cholesterol (LDL-C) level was calculated with the following equation $^{15)}$ : LDL-C = TC $-\mathrm{HDL}-\mathrm{C}-\mathrm{TG} / 5.0$ (mg/dl). VEGF, Ang 1, Ang 2, and follistatin levels were analyzed using an ELISA kit (R\&D Systems, Minneapolis, MN, USA). First, $100 \mu 1$ of capture antibody was incubated overnight at room temperature and washed 3 times. The samples and the standard were then combined and treated with detection antibody. Then, streptavidin-horseradish peroxidase and substrate solution were added, the reaction was terminated with the stop solution, and results were immediately obtained by optical density of each well using microplate reader set to $450 \mathrm{~nm}^{16)}$.

The mean and standard deviation of data obtained in our study were calculated using the SPSS Statistics Package for Windows Version 20.0 (SPSS, Armonk, NY, USA). Pre- and post-data were analyzed using the paired t-test within-group differences and the independent t-test for differences between the groups. A statistically significant level for all data was defined as $\alpha=0.05$.

Table 1. Combined open kinetic chain and closed kinetic chain training programs using pulley exercise machines

\begin{tabular}{llc}
\hline Item & Contents & Time (min) \\
\hline Warm up & Stretching & $10 \mathrm{~min}$ \\
& Chest press & \\
& Shoulder press & \\
& Pulley curl & $40 \mathrm{~min}$ \\
OKC (60\% 1RM, 10 rep, 2 sets) and & Push down & \\
CKC (10 rep, 2 sets) pulley training & Lat pull down & \\
& Knee extension & \\
& Reg curl & $10 \mathrm{~min}$ \\
\hline
\end{tabular}




\section{RESULTS}

Changes in body composition of subjects are shown in Table 2. There was no difference in height, weight, and BMI between the groups. After 8 weeks of training, the results of the serum lipids test (Table 3) were as follows: there was no significant difference according to time or group for TC, FFA, HDL-C, and LDL-C, but TG decreased significantly after the exercise $(\mathrm{p}<0.05)$. The results for isokinetic muscle strength after 8 weeks of training are shown in Tables 4 and 5 . After 8 weeks of training, muscle strength in the flexors and extensors of the trunk $\left(60^{\circ} / \mathrm{s}\right)$ and knee $\left(60^{\circ} / \mathrm{s}\right)$ were improved $(\mathrm{p}<0.05)$. The anaerobic power of each group is shown in Table 6. AP, PP, and PPS increased significantly for the PT group after training compared to before training $(\mathrm{p}<0.05)$. The changes in angiogenesis factors and follistatin after 8 weeks of training are shown in Table 7. Ang 1 increased $25 \%$ in the CO group $(\mathrm{p}<0.05)$ and $48 \%$ in the PT group $(\mathrm{p}<0.05)$ after training. VEGF and follistatin also increased significantly after training in the PT group $(\mathrm{p}<0.05)$.

Table 2. Physical characteristics of the subjects

\begin{tabular}{lrrcc}
\hline Variable & \multicolumn{3}{c}{ CO } & \multicolumn{2}{c}{ PT } \\
\cline { 2 - 5 } & \multicolumn{1}{c}{ Pre } & Post & Pre & Post \\
\hline Height $(\mathrm{cm})$ & $173.2 \pm 2.5$ & $173.5 \pm 2.5$ & $173.7 \pm 1.78$ & $174.1 \pm 1.6$ \\
Weight $(\mathrm{kg})$ & $66.5 \pm 2.7$ & $67.5 \pm 2.8$ & $68.8 \pm 2.7$ & $69.5 \pm 2.6$ \\
BMI $\left(\mathrm{kg} / \mathrm{m}^{2}\right)$ & $22.3 \pm 1.2$ & $22.6 \pm 1.2$ & $22.8 \pm 0.8$ & $22.9 \pm 0.9$ \\
Body fat $(\%)$ & $17.4 \pm 2.0$ & $17.9 \pm 2.2$ & $19.5 \pm 1.6$ & $17.9 \pm 1.6^{*}$ \\
LBM $(\mathrm{kg})$ & $54.7 \pm 1.3$ & $55.0 \pm 1.2$ & $55.0 \pm 1.2$ & $56.8 \pm 1.1^{*}$ \\
\hline
\end{tabular}

Values are mean \pm SE.

BMI: body mass index; LBM: lean body mass; CO: control group; PT: pulley training group

$* \mathrm{p}<0.05$ vs. Pre

Table 3. Lipid profiles

\begin{tabular}{lcccc}
\hline Variable & \multicolumn{2}{c}{ CO } & PT \\
\cline { 2 - 5 } & Pre & Post & Pre & Post \\
\hline TC $(\mathrm{mg} / \mathrm{dL})$ & $154.4 \pm 8.2$ & $153.9 \pm 8.5$ & $158.8 \pm 13.9$ & $149.5 \pm 8.3$ \\
TG $(\mathrm{mg} / \mathrm{dL})$ & $75.6 \pm 5.4$ & $70.8 \pm 4.9$ & $72.2 \pm 3.8$ & $55.2 \pm 2.4^{*} \#$ \\
FFA $(\mu \mathrm{Eq} / \mathrm{L})$ & $466.8 \pm 59.7$ & $512.9 \pm 74.1$ & $471.1 \pm 69.0$ & $499.6 \pm 38.1$ \\
HDL-c $(\mathrm{mg} / \mathrm{dL})$ & $51.6 \pm 2.5$ & $51.7 \pm 1.9$ & $50.6 \pm 1.4$ & $47.5 \pm 1.6$ \\
LDL-c $(\mathrm{mg} / \mathrm{dL})$ & $87.7 \pm 8.6$ & $88.0 \pm 9.9$ & $93.7 \pm 13.8$ & $88.9 \pm 9.3$ \\
\hline
\end{tabular}

Values are mean \pm SE.

CO: control group; PT: pulley training group

$* \mathrm{p}<0.05$ vs. Pre, $\# \mathrm{p}<0.05$ vs. CO

Table 4. The results for trunk $(60 \%)$ muscle strength after 8 weeks of training

\begin{tabular}{lcccc}
\hline Variable & \multicolumn{2}{c}{ CO } & \multicolumn{2}{c}{ PT } \\
\cline { 2 - 5 } & Pre & Post & Pre & Post \\
\hline FPT $(\mathrm{N} \cdot \mathrm{m})$ & $224.2 \pm 30.1$ & $218.2 \pm 25.9$ & $227.8 \pm 17.7$ & $298.7 \pm 19.7^{* \#}$ \\
FPT\%BW (N·m) & $291.8 \pm 20.5$ & $277.1 \pm 10.1$ & $274.8 \pm 19.9$ & $362.4 \pm 16.3^{*} \#$ \\
FWR (N·m) & $139.7 \pm 10.9$ & $143.9 \pm 12.9$ & $143.2 \pm 13.4$ & $186.2 \pm 7.8^{*} \#$ \\
FWR\%BW (N·m) & $215.6 \pm 18.0$ & $196.3 \pm 12.4$ & $195.9 \pm 13.4$ & $261.3 \pm 15.3^{*} \#$ \\
EPT (N·m) & $250.9 \pm 8.1$ & $247.8 \pm 8.8$ & $232.3 \pm 9.6$ & $287.3 \pm 11.0^{* \#}$ \\
EPT\%BW (N·m) & $329.9 \pm 19.2$ & $323.6 \pm 20.5$ & $362.8 \pm 19.2$ & $406.5 \pm 19.2^{* \#}$ \\
EWR (N·m) & $249.9 \pm 12.8$ & $255.3 \pm 11.5$ & $256.5 \pm 11.3$ & $292.2 \pm 13.5^{*} \#$ \\
EWR\%BW (N·m) & $340.4 \pm 24.7$ & $317.8 \pm 23.4$ & $364.4 \pm 24.4$ & $422.1 \pm 19.0^{*} \#$ \\
\hline
\end{tabular}

Values are mean \pm SE.

FPT: flexor peak torque; FPT\%BW: FPT per body weight; FWR: flexor work per repetition; FWR\%BW: FWR per body weight; EPT: extensor peak torque; EPT\%BW: EPT per body weight; EWR: extensor work per repetition; EWR\%BW: EWR per body weight; CO: control group; PT: pulley training group 


\section{DISCUSSION}

Muscle strength and function are affected by muscle atrophy with aging, musculoskeletal disorders, sedentary living, and bed confinement ${ }^{17}, 18$ ). However, regular resistance exercise improves muscle function, increases strength after damage, and prevents decline in muscle strength despite aging ${ }^{19,20)}$. In particular, combined OKC and CKC training can be considered essential for muscle strength improvement and stabilization. Hence, the present study analyzed the effect of using pulley exercise machines that enable combined $\mathrm{OKC}$ and CKC training on muscle strength anaerobic power and angiogenesis factors.

Eight weeks of this combined training was effective in significantly increasing muscle strength in the flexors and extensors of the trunk and knee $(\mathrm{p}<0.05)$. This is consistent with previous studies reporting that resistance exercise increases muscle strength ${ }^{12,21-23)}$. Anaerobic exercise capacity refers to the muscle endurance and contractile strength that results from anaerobic metabolism and is highly correlated with strength and endurance ${ }^{24)}$. A 30-s Wingate anaerobic exercise capacity

Table 5. The results for knee $(60 \%)$ muscular strength after 8 weeks of training

\begin{tabular}{|c|c|c|c|c|}
\hline \multirow[t]{2}{*}{ Variable } & \multicolumn{2}{|c|}{$\mathrm{CO}$} & \multicolumn{2}{|c|}{ PT } \\
\hline & Pre & Post & Pre & Post \\
\hline $\operatorname{FPT}(\mathrm{N} \cdot \mathrm{m})$ & $88.8 \pm 8.3$ & $82.2 \pm 10.2$ & $83.2 \pm 6.8$ & $105.3 \pm 5.8^{* \#}$ \\
\hline $\mathrm{FWR}(\mathrm{N} \cdot \mathrm{m})$ & $109.4 \pm 8.0$ & $107.8 \pm 9.7$ & $109.6 \pm 8.5$ & $130.2 \pm 9.2 * \#$ \\
\hline FWR\%BW $(\mathrm{N} \cdot \mathrm{m})$ & $161.2 \pm 12.8$ & $154.9 \pm 12.4$ & $162.6 \pm 11.2$ & $198.1 \pm 11.6^{* \#}$ \\
\hline EPT\%BW $(\mathrm{N} \cdot \mathrm{m})$ & $242.1 \pm 15.1$ & $244.4 \pm 14.2$ & $245.2 \pm 9.3$ & $277.5 \pm 9.2 * \#$ \\
\hline $\operatorname{EWR}(\mathrm{N} \cdot \mathrm{m})$ & $182.9 \pm 7.9$ & $183.2 \pm 9.5$ & $184.5 \pm 8.5$ & $224.4 \pm 11.4 * \#$ \\
\hline EWR\%BD $(\mathrm{N} \cdot \mathrm{m})$ & $264.7 \pm 14.9$ & $266.7 \pm 16.7$ & $268.1 \pm 11.5$ & $303.7 \pm 12.4 * \#$ \\
\hline
\end{tabular}

Values are mean \pm SE.

FPT: flexor peak torque; FPT\%BW: FPT per body weight; FWR: flexor work per repetition; FWR\%BW: FWR per body weight; EPT: extensor peak torque; EPT\%BW: EPT per body weight; EWR: extensor work per repetition; EWR\%BW: EWR per body weight; $\mathrm{CO}$ : control group; $\mathrm{PT}$ : pulley training group.

$* \mathrm{p}<0.05$ vs. Pre, $\# \mathrm{p}<0.05$ vs. $\mathrm{CO}$

Table 6. The anaerobic power of each group

\begin{tabular}{lcccc}
\hline Variable & \multicolumn{2}{c}{ CO } & \multicolumn{2}{c}{ PT } \\
\cline { 2 - 5 } & Pre & Post & Pre & Post \\
\hline AP (w) & $535.1 \pm 16.2$ & $540.9 \pm 19.9$ & $557.8 \pm 17.2$ & $597.6 \pm 12.8^{*}$ \\
PP (w) & $672.8 \pm 32.2$ & $696.2 \pm 34.7$ & $675.7 \pm 21.3$ & $741.3 \pm 21.8^{*}$ \\
PPS (rpm) & $138.8 \pm 6.9$ & $142.4 \pm 5.1$ & $134.3 \pm 3.8$ & $146.3 \pm 4.9 *$ \\
PAT (s) & $6.6 \pm 0.6$ & $6.5 \pm 0.7$ & $10.8 \pm 1.5$ & $8.09 \pm 1.3$ \\
\hline
\end{tabular}

Values are mean \pm SE.

AP: average power; PP: peak power; PPS: peak pedaling speed; PAT: peak attainment time; CO: control group; PT: pulley training group

$* \mathrm{p}<0.05$ vs. Pre

Table 7. The changes in angiogenesis factors and follistatin after 8 weeks of training

\begin{tabular}{lcccc}
\hline Variable & \multicolumn{2}{c}{ CO } & & PT \\
\cline { 2 - 5 } & Pre & Post & Pre & Post \\
\hline VEGF $(\mathrm{pg} / \mathrm{mL})$ & $47.0 \pm 1.3$ & $47.7 \pm 0.9$ & $50.3 \pm 3.0$ & $52.8 \pm 4.0^{*}$ \\
Ang 1 $(\mathrm{pg} / \mathrm{mL})$ & $403.9 \pm 29.2$ & $504.7 \pm 24.0^{*}$ & $348.4 \pm 18.5$ & $540.6 \pm 39.1^{*}$ \\
Ang 2 $(\mathrm{pg} / \mathrm{mL})$ & $17.9 \pm 0.5$ & $17.1 \pm 0.4$ & $16.5 \pm 0.7$ & $16.3 \pm 0.7$ \\
Follistatin $(\mathrm{pg} / \mathrm{mL})$ & $22.2 \pm 3.8$ & $24.9 \pm 2.8$ & $23.7 \pm 3.4$ & $29.1 \pm 3.9^{*}$ \\
\hline
\end{tabular}

Values are mean \pm SE.

VEGF: vascular endothelial growth factor; Ang 1: angiopoietin 1; Ang 2: angiopoietin 2; CO: control group; PT: pulley training group

$* \mathrm{p}<0.05$ vs. Pre 
assessment method is widely used to determine anaerobic power. In this study, the anaerobic AP and PP results after 8 weeks of combined OCK and CKC training using pulley exercise machines improved significantly in the PT group compared to the CO group $(\mathrm{p}<0.05)$. These results are consistent with previous reports that the 30 -s Wingate anaerobic test increased PP values after resistance training ${ }^{25}$.

The density and ratio of capillaries in muscle of VEGF-deficient mice were reportedly lower ${ }^{26)}$. Previous studies reported that angiogenesis in human and animal muscle tissue was induced by exercise ${ }^{27-30)}$. Gavin et al. ${ }^{31)}$ reported that acute knee extensor exercise at an intensity of 60-80\% increased blood VEGF mRNA and VEGF protein levels between 2 and $4 \mathrm{~h}$ after exercise. Yeo et al. ${ }^{16)}$ reported that resistance exercise for 8 weeks at $60 \%$ or $90 \%$ intensity increased serum VEGF level in both groups. The present study showed that blood VEGF levels increased significantly after 8 weeks of combined OKC and CKC training using pulleys $(\mathrm{p}<0.05)$, which was consistent with previous studies. Angiopoietins are key elements of the process of angiogenesis. The stability of capillaries is reportedly promoted when the concentration of Ang 1 is higher than that of Ang 2 and is reduced when the concentration of Ang 2 is higher than that of Ang 132, 33). Ang 2 levels in this study did not change in either group. However, Ang 1 increased in the PT group. Therefore, 8 weeks of combined OKC and CKC training can increase Ang 1 and may be more effective in promoting capillary stability compared to the CO group.

Follistatin increase muscle mass and promotes muscle growth by neutralizing myostatin, which has a negative effect on mass and growth ${ }^{34,35)}$. Muscle mass increased in follistatin-overexpressing transgenic mice and reduction in follistatin caused a decrease in gastrocnemius mass ${ }^{36}$. Therefore, follistatin proved to be an important factor in muscle formation. Acute knee extension in postmenopausal women increased follistatin levels in skeletal muscle, and resistance training at 85-90\% intensity increased serum follistatin levels and muscle strength ${ }^{37)}$. The results of the present study showed a significant increase in follistatin in the PT group $(\mathrm{p}<0.05)$ after 8 weeks of combined training.

The results of this study indicate that 8 weeks of combined $\mathrm{OKC}$ and $\mathrm{CKC}$ training using pulley exercise machines increased serum VEGF, Ang 1, and follistatin and improved AP and PP in tests of anaerobic capacity. The training also improved flexor and extensor strength in the trunk and knee. Hence, 8 weeks of combined training effectively increased biochemical factors that are closely related to muscle growth and improved muscle strength in the trunk and knee. Future studies are needed to perform histological analysis of neuromuscular activation, muscle hypertrophy, and angiogenesis factors following combined training.

\section{ACKNOWLEDGEMENT}

This research was supports by Dong-A University research fund.

\section{REFERENCES}

1) Karandikar N, Vargas OO: Kinetic chains: a review of the concept and its clinical applications. PM R, 2011, 3: 739-745. [Medline] [CrossRef]

2) Rogol IM, Ernst G, Perrin DH: Open and closed kinetic chain exercises improve shoulder joint reposition sense equally in healthy subjects. J Athl Train, 1998, 33: 315-318. [Medline]

3) Kwon YJ, Park SJ, Jefferson J, et al.: The effect of open and closed kinetic chain exercises on dynamic balance ability of normal healthy adults. J Phys Ther Sci, 2013, 25: 671-674. [Medline] [CrossRef]

4) Shweiki D, Itin A, Soffer D, et al.: Vascular endothelial growth factor induced by hypoxia may mediate hypoxiainitiated angiogenesis. Nature, 1992, 359: 843-845. [Medline] [CrossRef]

5) Egginton S: Invited review: activity-induced angiogenesis. Pflugers Arch, 2009, 457: 963-977. [Medline] [CrossRef]

6) Waltenberger J, Claesson-Welsh L, Siegbahn A, et al.: Different signal transduction properties of KDR and Flt1, two receptors for vascular endothelial growth factor. J Biol Chem, 1994, 269: 26988-26995. [Medline]

7) Wagner PD, Olfert IM, Tang K, et al.: Muscle-targeted deletion of VEGF and exercise capacity in mice. Respir Physiol Neurobiol, 2006, 151: 159-166. [Medline] [CrossRef]

8) Li T, Liu Z, Jiang K, et al.: Angiopoietin2 enhances doxorubin resistance in HepG2 cells by upregulating survivin and Ref-1 via MSK1 activation. Cancer Lett, 2013, 337: 276-284. [Medline] [CrossRef]

9) Suri C, Jones PF, Patan S, et al.: Requisite role of angiopoietin-1, a ligand for the TIE2 receptor, during embryonic angiogenesis. Cell, 1996, 87: 1171-1180. [Medline] [CrossRef]

10) Hoier B, Nordsborg N, Andersen S, et al.: Pro- and anti-angiogenic factors in human skeletal muscle in response to acute exercise and training. J Physiol, 2012, 590: 595-606. [Medline] [CrossRef]

11) Lee SJ: Regulation of muscle mass by myostatin. Annu Rev Cell Dev Biol, 2004, 20: 61-86. [Medline] [CrossRef] 
12) Romero-Arenas S, Blazevich AJ, Martínez-Pascual M, et al.: Effects of high-resistance circuit training in an elderly population. Exp Gerontol, 2013, 48: 334-340. [Medline] [CrossRef]

13) Timmons JA, Jansson E, Fischer H, et al.: Modulation of extracellular matrix genes reflects the magnitude of physiological adaptation to aerobic exercise training in humans. BMC Biol, 2005, 3: 19. [Medline] [CrossRef]

14) O'Shea JP, Wegner J: Power weight training and the female athlete. Physician Sports Med, 1981, 9: 109-120.

15) Friedewald WT, Levy RI, Fredrickson DS: Estimation of the concentration of low-density lipoprotein cholesterol in plasma, without use of the preparative ultracentrifuge. Clin Chem, 1972, 18: 499-502. [Medline]

16) Yeo NH, Woo J, Shin KO, et al.: The effects of different exercise intensity on myokine and angiogenesis factors. J Sports Med Phys Fitness, 2012, 52: 448-454. [Medline]

17) Winters KM, Snow CM: Detraining reverses positive effects of exercise on the musculoskeletal system in premenopausal women. J Bone Miner Res, 2000, 15: 2495-2503. [Medline] [CrossRef]

18) Demircioglu DT, Paker N, Erbil E, et al.: The effect of neuromuscular electrical stimulation on functional status and quality of life after knee arthroplasty: a randomized controlled study. J Phys Ther Sci, 2015, 27: 2501-2506. [Medline] [CrossRef]

19) Lustosa LP, Silva JP, Coelho FM, et al.: Impact of resistance exercise program on functional capacity and muscular strength of knee extensor in pre-frail community-dwelling older women: a randomized crossover trial. Rev Bras Fisioter, 2011, 15: 318-324. [Medline] [CrossRef]

20) Cho SI, An DH: Effects of a fall prevention exercise program on muscle strength and balance of the old-old elderly. J Phys Ther Sci, 2014, 26: 1771-1774. [Medline] [CrossRef]

21) Kemmler WK, Lauber D, Engelke K, et al.: Effects of single- vs. multiple-set resistance training on maximum strength and body composition in trained postmenopausal women. J Strength Cond Res, 2004, 18: 689-694. [Medline]

22) Rabelo HT, Bezerra LA, Terra DF, et al.: Effects of 24 weeks of progressive resistance training on knee extensors peak torque and fat-free mass in older women. J Strength Cond Res, 2011, 25: 2298-2303. [Medline] [CrossRef]

23) Granacher U, Goesele A, Roggo K, et al.: Effects and mechanisms of strength training in children. Int J Sports Med, 2011, 32: 357-364. [Medline] [CrossRef]

24) Serresse O, Ama PF, Simoneau JA, et al.: Anaerobic performances of sedentary and trained subjects. Can J Sport Sci, 1989, 14: 46-52. [Medline]

25) Fatouros IG, Kambas A, Katrabasas I, et al.: Strength training and detraining effects on muscular strength, anaerobic power, and mobility of inactive older men are intensity dependent. Br J Sports Med, 2005, 39: 776-780. [Medline] [CrossRef]

26) Olfert IM, Howlett RA, Tang K, et al.: Muscle-specific VEGF deficiency greatly reduces exercise endurance in mice. J Physiol, 2009, 587: 1755-1767. [Medline] [CrossRef]

27) Gustafsson T, Knutsson A, Puntschart A, et al.: Increased expression of vascular endothelial growth factor in human skeletal muscle in response to short-term one-legged exercise training. Pflugers Arch, 2002, 444: 752-759. [Medline] [CrossRef]

28) Richardson RS, Wagner H, Mudaliar SR, et al.: Exercise adaptation attenuates VEGF gene expression in human skeletal muscle. Am J Physiol Heart Circ Physiol, 2000, 279: H772-H778. [Medline]

29) Olfert IM, Breen EC, Mathieu-Costello O, et al.: Skeletal muscle capillarity and angiogenic mRNA levels after exercise training in normoxia and chronic hypoxia. J Appl Physiol 1985, 2001, 91: 1176-1184. [Medline]

30) Prior BM, Lloyd PG, Yang HT, et al.: Exercise-induced vascular remodeling. Exerc Sport Sci Rev, 2003, 31: 26-33. [Medline] [CrossRef]

31) Gavin TP, Robinson CB, Yeager RC, et al.: Angiogenic growth factor response to acute systemic exercise in human skeletal muscle. J Appl Physiol 1985, 2004, 96: 19-24. [Medline] [CrossRef]

32) Gale NW, Yancopoulos GD: Growth factors acting via endothelial cell-specific receptor tyrosine kinases: VEGFs, angiopoietins, and ephrins in vascular development. Genes Dev, 1999, 13: 1055-1066. [Medline] [CrossRef]

33) Yamauchi A, Ito Y, Morikawa M, et al.: Pre-administration of angiopoietin-1 followed by VEGF induces functional and mature vascular formation in a rabbit ischemic model. J Gene Med, 2003, 5: 994-1004. [Medline] [CrossRef]

34) Haidet AM, Rizo L, Handy C, et al.: Long-term enhancement of skeletal muscle mass and strength by single gene administration of myostatin inhibitors. Proc Natl Acad Sci USA, 2008, 105: 4318-4322. [Medline] [CrossRef]

35) Hansen AH, Nyberg M, Bangsbo J, et al.: Exercise training alters the balance between vasoactive compounds in skel- 
etal muscle of individuals with essential hypertension. Hypertension, 2011, 58: 943-949. [Medline] [CrossRef]

36) Lee SJ, McPherron AC: Regulation of myostatin activity and muscle growth. Proc Natl Acad Sci USA, 2001, 98: 9306-9311. [Medline] [CrossRef]

37) Willoughby DS: Effects of heavy resistance training on myostatin mRNA and protein expression. Med Sci Sports Exerc, 2004, 36: 574-582. [Medline] [CrossRef] 